\title{
Analysis of strategy for meeting students' information needs in the digital era
}

\author{
Gardito Qastalani ${ }^{1}$ and Kiki Fauziah, ${ }^{2, *}$ \\ ${ }^{1}$ Undergraduate student. Department of Library and Information Science, Universitas Indonesia, \\ Depok, West Java - 16424, Indonesia \\ ${ }^{2}$ Department of Library and Information Science, Universitas Indonesia, Depok, West Java - 16424, \\ Indonesia
}

\begin{abstract}
This research focused on the strategy of fulfilling students' information needs in the digital era. The purpose of this study is to identify strategies for meeting the informa6tion needs of students in the current digital era. This study uses a qualitative approach and case study method. Data collection is done by interviewing, observing, and analysing documents. The results of this study show that the strategy of fulfilling the information needs of students is by prioritising the internet such as ejournal, e-book, or search engine.
\end{abstract}

\section{Introduction}

In this era, information becomes a primary need for each individuals. All levels of society need information, just as doctors who need information about the development of a type of disease to find an antidote. The university academic community such as lecturers, students and staff/employees also need information. Lecturers need information for teaching and research materials, whereas students need information to complete lecture assignments and final assignments, and staff/employees need information to do their work. Furthermore, people need information to add insight and help in solving any problems in daily life.

Each person are different, but everyone tends to meet the most urgent or most needed. According to Case (2012), he states that humans tend to prioritise the most needed one such as the physiological needs, which are food, drink, clothing and a place to live. The one that is most needed according to Case [1] is a need that if it is not fulfilled, it will interfere with everyday life. Information need is a means to solve the problem for everyone, because problems usually arise due to the individual who does not know the solution, and the answer to that solution is to get the information. In other words, information needs arise when someone is aware that he or she do not have, or lack of knowledge or understanding to achieve the goals, to answer questions, and so on [2].

The development of information that is more easily accessed and accepted by public has an impact on the importance of society's knowledge in how to evaluate and use the information wisely and precisely that is tailored to their information needs. This is related to the importance of quality education in using information in order to create long life

\footnotetext{
* Corresponding author: kikifauziah@ui.ac.id
} 
learning for public. The same is true for students in nowadays digital era. Students who are easier to access and obtain information should also have skills to find, utilize, and evaluate the information by adjusting the information needs they want.

The previous research related to the information needs is a thesis written by Henny Setia Ningsih [3] entitled "Information Needs and its Fulfillment: Case Study of Youth in the City". This study aims to understand the information needs and addressing their needs. The approach used is qualitative with the case study research method. Results from this research showing that teenagers meet their information needs by using some resources, such as electronic media, printed media and information from other people.

The next research is a thesis written by Narenda Aulia Deanawa [4], titled "Analysis of Elderly's Information Needs in Surabaya City". This study aims to identify what information is needed by the elderly as the patron of library users. The researcher used the concept from David Nicholas to describe the characteristics of information needs and the obstacles encountered when fulfilling information needs. This study uses descriptive quantitative methods. The sampling method in this study uses multistage random sampling with a total sample of 100 respondents. The results of this study indicate that the elderly of Surabaya City like the topics of Health, Religion and Sports information, with $100 \%, 100 \%$ and $89 \%$ respectively. It was also known that the elderly needed information when they were facing problems with related information topics, which amounted to $52 \%$. Older adults also like printed information in the form of newspapers, namely as much as $43 \%$ and electronic information in the form of television as much as $73 \%$. Sources of information that are older people use are friends, family, and information experts, with sequential presentations of $70 \%, 65 \%$ and $64 \%$ respectively, because the source of information is easily accessible.

As for the difference between this research with the previous one is that there is not yet research related strategy for meeting students' information needs especially on a final-year student. In short, this research aims to identify the fulfilment strategy of the students' information needs in the current digital era.

\section{Literature review}

\subsection{Information needs}

Information is knowledge about a subject, issue, and process. Information is a stored knowledge; information is as a data in a particular environment which means that the information is obtained through the phenomena that occur in the environment; information is as part of the communication process in which people exchange information while communicating; and information is as a resource whereby when someone get information from others, there is a possibility of increasing the quality of information depending on the understanding of the recipient of information [5]. According to the Online Dictionary for Library and Information Science (ODLIS) [6], information is a data that is presented in a form that can be read where the meaning of the data has been adjusted to the purpose of the information. In other words, information is the conveyed message by using communication as the medium. The message that is contained in the information is subjective in the sense that it is beneficial or not, depend on the person who uses the information.

Definition of information needs has brought up by many experts. Arsland [7] in its essay, quoting Zipper (1993), who states that information needs are considered as a gap in understanding something, namely when a person experiences a situation where they have to make a decision, solve a problem or understand something. Thompson in Yusuf [8] said that information needs are something that is objective, which is something that individuals 
need, in order to support their profession. Wilson [9] says that humans have three needs, they are physiological, emotional, and cognitive needs. Wilson in Yusuf [8] said that information needs are influenced by several factors, such as available sources of information; the use of this information; background, motivation, professional orientation and characteristics of the individual itself. Another factor according to Wilson in Yusuf [8] is socio-political, economic, and policy from the use of information needed.

\subsection{Strategy for meeting students' information needs}

According to Karas \& Green [10], the majority of students are interested in getting information in a fast and easy way to complete their assignments. College student meet their needs of the information via the internet and look at the previous research. When facing a problem in their research, the students claimed that the problem was caused by a lack of research on the subject they were studying. Some students fulfil their information needs based on information sources that are easy to read and access because they have a limited time to compile their research. Students tend to rarely use printed information sources because usually information resources that are available on the internet is more comfortable and faster. Those, who use the internet and previous research as fulfilling their own information needs, claim that there is no need to check the validity of the data because according to them, information on the internet and previous research is valid. Although technology has made it easier for students to live with search engines and access to databases which contain previous studies, students become less attentive to information quality [10].

The strategy to fulfil the information needs in the age of technology has focused on the use of websites, research databases, and other digital sources. Many students do not fulfil their information needs through libraries, because they think that there are faster and easier ways [10]. Metzger [11] stated that there is a worry when students use the internet as a source of information, and the information they get on the internet is misleading or inaccurate.

\section{Method}

This study uses a qualitative approach to the case study method. Case studies are research strategies that are carried out by careful investigation of a program, event, activity, process, or group [12]. The time, place and activity limit the cases in this study. This research was conducted to determine the strategy of meeting the information needs of Library and Information Science students in the digital era. Selection of informants for this study is the final semester students in library and information science program year 2014. Five informants were chosen by using purposive sampling method. The criteria for informants are students in the final semester of the library and information science program, class of 2014; coming from the outside of the city and from within the city; having information that is needed in this study; understand the strategy of meeting their information needs when searching information; having a career plan after graduation; writing a thesis; willing to be interviewed; and voluntarily provide information to researchers.

Data collection was carried out by in-depth interviews with each informant. The interview questions are related to the information needs of students and the strategies that they do in fulfilling the information needs. Interviews were conducted in 60 minutes average time per informant. It took place from February 2018 to April 2018. The location of the study was conducted at the Faculty of Humanities, University of Indonesia. 


\section{Discussion}

Based on the results of the interviews with informants, it can be seen that they need information related to thesis topics, job vacancies, and entertainment. Information related to the thesis topic is the primary information needed by students at this time. Meanwhile, the employee-related information and entertainment become secondary and tertiary information for the informant.

Table 2. Strategies for meeting students'information needs.

\begin{tabular}{|c|c|}
\hline Informant & Strategies for Meeting the Information Needs \\
\hline Wati & $\begin{array}{l}\text { 1. Search for books in the University of Indonesia Library } \\
\text { and Faculty of Social and Political Science (FISIP) } \\
\text { library related to the information needed; } \\
\text { 2. Use internet media to access journals namely Emerald } \\
\text { Journal and Proquest Journal; } \\
\text { 3. The strategy in tracing information on the internet is to } \\
\text { collect the information needed first without considering } \\
\text { the document format, updates, or originality. }\end{array}$ \\
\hline Mawar & $\begin{array}{l}\text { 1. Prioritize internet media such as e-journal (Emerald); } \\
\text { 2. Rely on the university library site to find e-journals; } \\
\text { 3. Focus on information renewal. }\end{array}$ \\
\hline Soni & $\begin{array}{l}\text { 1. Prioritize internet media such as Google; } \\
\text { 2. Utilize printed collections such as books that are } \\
\text { available in the university library if the information } \\
\text { obtained from the Internet has not met yet; } \\
\text { 3. For the needs of job vacancies, he looks at the type of } \\
\text { institutions first. Then are those institutions opening a } \\
\text { job vacant on Library Science or not. }\end{array}$ \\
\hline Saiful & $\begin{array}{l}\text { 1. Use internet media to search database journals on the } \\
\text { Indonesian National Library website; } \\
\text { 2. The strategy in tracing information on the internet is by } \\
\text { gathering the information needed first without } \\
\text { considering the document format, updates, or originality. }\end{array}$ \\
\hline Rudi & $\begin{array}{l}\text { 1. Prioritize searching for information via the internet, } \\
\text { namely on e-journals like Emerald. Then, if the internet } \\
\text { information has not been fulfilled, he looks for a } \\
\text { collection of books that is available in the library; } \\
\text { 2. Focus on the conformity and up-to-date information. }\end{array}$ \\
\hline
\end{tabular}

In the strategy to fulfil the information needs, students have different strategies that are influenced by their background, economy, and knowledge. Likewise, strategies for meeting information needs also vary depending on the type of information needed. As well as students who are seeking information related to the academic field namely thesis writing. They then continue to use the book collection as complementary literature in the completion of their tasks in the library. This indicates that students still rely on the library as a place to get information on book format for free without spending money. Likewise, with another type of collections, students also rely on the free e-journal access via the University library account website or e-journals that are subscribed by the Indonesian National Library. Whereas, for the fulfilment of secondary information needs such as job 
vacancies and tertiary information needs such as entertainment, they rely more on the internet. The following is a table that explains the strategy for meeting the information needs of informants.

Based on the table 2, it shows that students in the digital age are rely more on the information that is from the internet and its format is electronic compared to printed format. According to the informants, it is due to convenient access and the way to get online information compared to printed. This corresponding to research conducted by Karas \& Green [10] which stated that students fulfil their information needs via the internet and previous research. Besides, the economic factor also becomes a consideration for students to choose the easy-access and rely on the internet as their fulfilment media on information needs.

\section{Conclusion}

Based on the results of the study, students tend to have diverse strategies for meeting their information needs. However, in meeting it, the most commonly used strategy is via the internet. Students use the internet because they feel that it offers speed and ease in meeting information needs and more economical.

Furthermore, the internet used by informants to meet their information needs is online media. The use of online media through the internet as a strategy for meeting informants' information needs was also seen when informants needed information for entertainment and looking for work. All informants, who want to meet their entertainment needs and find work, usually use the internet either through websites or social media. This phenomenon is caused by the ease of accessing the internet, which can be accessed anytime and anywhere. Even so, the speed offered by the internet in meeting their information needs can accelerate the fulfilment of students' information needs.

\section{Acknowledgements}

This research is funded by Hibah PITTA 2018 from Directorat of Research and Community Engagement, Universitas Indonesia No. 1957/UN2.R3.1/HKP.05.00/2018.

\section{References}

1. D.O. Case, Looking for information: a survey of research on information seeking, needs, and behavior (Emerald Group Publishing Limited, UK, 2012)

2. S. Batley, Information Architecture for Information Professionals (Chandos Publishing, England, 2007)

3. H.S. Ningsih, Kebutuhan Informasi dan Pemenuhan Kebutuhan akan Informasi: Studi Kasus Remaja Kota (2012)

4. N.A. Deanawa, Analisis Kebutuhan Informasi Lansia di Kota Surabaya (2016)

5. A.D. Madden, Emerald Insight 52, 343-349 (2000)

6. J.M. Reitz, Online Dictionary for Library and Information Science (2004-2014)

7. A. Arsland, Studi tentang kebutuhan dan pencarian informasi anggota dewan perwakilan rakyat Republik Indonesia dalam proses penerbitan suatu undang-undang atas usul inisiatif (UI, Depok, 2001)

8. T.I. Yusuf, Library Philosophy and Practice .

9. T. Wilson, Information research 5, 3 (2000)

10. M. Karas, R. Green, Community \& Junior College Libraries, 103-109 (2007) 
11. M.J. Metzger, A.J. Flanagin, L. Zwarun, Computers \& Education, 271-290 (2003)

12. J.W. Creswell, Research design: pendekatan kualitatif, kuantitatif, dan mixed (PT Pustaka Pelajar, Jogjakarta, 2010) 